\title{
A Quest For Effective Vision: Evidence From Australia
}

Sooksan Kantabutra, (E-mail:sooksan.k@cmmu.net), College of Management, Mahidol University, Thailand Gayle C. Avery, (E-mail:gayle.avery@gsm.mq.edu.au), Macquarie Graduate School of Management, Sydney, Australia

\begin{abstract}
While leaders are widely exhorted to espouse visions, very little is known about what characterizes "effective" visions. A research model was tested to examine relationships between seven literature-derived vision attributes (brevity, clarity, future orientation, stability, challenge, abstractness, and desirability or ability to inspire) and content (customer and staff satisfaction imageries), and the performance outcomes of customer and staff satisfaction in retail stores in Sydney, Australia. Extending previous research, literature-derived Store Manager, Staff and Organizational Factors were simultaneously taken into account. Findings endorse the importance of espousing a vision characterized by the seven attributes, while vision content rendered no significant effects. The Store Manager and Staff Factors were found to create a significant impact on store performance, whereas the Organizational Factor was not significantly related to store performance.
\end{abstract}

\section{INTRODUCTION}

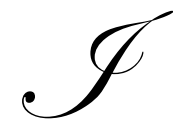

$\mathrm{n}$ a fast-changing world, the question is what kind of leadership is needed for organizations to survive and remain competitive. To many scholars, leadership with vision as a core component is the answer (Bass, 1990; Conger, 1991; Conger \& Kanungo, 1987; Tichy \& Divanna, 1986). In general, vision has been studied as part of charismatic leadership in a wide variety of samples and industries, predominantly at the individual level rather than at the business-unit and organizational levels. Generally positive findings between visionary leadership and individual follower performance, attitudes, and perceptions have been reported, with no published studies reporting a negative relation between charismatic/visionary leadership and individual performance. At the business-unit level, two studies of corporate managers (Barling, Weber, \& Kelloway, 1996; Howell \& Avolio, 1993) reported significant relationships between charismatic leadership and performance. At the organizational level, a major study found positive relationships between characteristics of CEO visions and venture growth, as measured by sales, profits, employment, and net worth, thereby supporting the view that vision is critical to broader organizational success (Baum, Locke, \& Kirkpatrick, 1998).

In terms of vision components, Baum et al.'s (1998) study is also the first to investigate relationships between vision attributes and vision content, and organizational performance. It was found that the vision attributes of brevity, clarity, future orientation, stability, challenge, abstractness, desirability or ability to inspire and vision content of venture growth imagery impacted venture growth positively, both directly and indirectly, via vision communication.

In general, examining what constitutes an effective vision has been little studied. Yet this is critical to researchers and practitioners who wish to understand the relationship between visionary leadership and organizational performance. Research into vision has generally focused on four aspects: development, articulation, communication, and implementation of the vision (e.g. Nanus, 1992; Quigley, 1993; Robbins \& Duncan, 1988; Sashkin, 1992; Wall, Solum, \& Sobol, 1992; Westley \& Mintzberg, 1989). In particular, no published studies have linked characteristics of visions specifically to retail business performance. 
This paper addresses some key issues in developing and realizing a vision, and tests a research model investigating "effective" vision components in the Australian retail business. Methodology, findings, and future research directions are discussed, and the conclusions include managerial implications.

\section{VISION COMPONENTS}

This section defines the term "vision" used in this paper. Two vision components suggested in the literature, namely vision attributes and vision content, and their operational definitions are then presented.

\section{Defining Vision}

Research into vision is complicated by the fact that the concept of vision is not clearly defined in the literature, with definitions ranging from a goal-oriented mental construct (Seeley, 1992) to a force field whose formative influence leaders can use to create a power, not a place (Wheatley, 1999). Avoiding the confusing definitional issue altogether, Baum et al. (1998) opted to define the term vision as each leader defines it, arguing that it is the leader's actual vision that guides his/her choices and actions. This pragmatic definitional approach is adopted in this study for two main reasons. First, each leader develops a vision in his/her own way, sometimes rationally and objectively, often intuitively and subjectively (Nanus, 1992). Second, visionary leadership can vary importantly from leader to leader in both the leader's style, the content of the leader's vision, and the context in which it takes root (Westley \& Mintzberg, 1989). Thus, in investigating any relationships between leader vision and organizational performance, it is essential to consider the visionary tools that the leader employs, rather than a possibly unrelated theoretical definition. Baum et al.'s (1998) approach of adopting what individual leaders regard as a vision offers a pragmatic way around the definitional confusion in the vision literature.

\section{Vision Attributes}

Although many leadership and business strategy theorists have postulated different attributes that a vision should have, some commonly shared attributes can be identified. Common attributes include: brevity (Baum et al. 1998; Locke, Kirkpartick, Wheeler, Schneider, Niles, Goldstein, Welsh, \& Chah., 1991), clarity (Baum et al., 1998; Jacobs \& Jaques, 1990; Locke et al., 1991; Nanus, 1992; Sashkin, 1988; Sims \& Larenzi, 1992; Williams -Brinkley, 1999), future orientation (Baum et al., 1998; Jacobs \& Jaques, 1990; Kotter, 1990; Lipton, 1996; Locke et al., 1991; Senge, 1990; Williams -Brinkley, 1999), stability (Baum et al., 1998; Locke et al., 1991), challenge (Baum et al., 1998; Locke et al., 1991; Nanus, 1992; Sashkin, 1988; Sims \& Lorenzi, 1992), abstractness (Baum et al., 1998; Locke et al., 1991), and desirability or ability to inspire (Baum et al., 1998; Locke et al., 1991; Sashkin, 1988; Sims \& Lorenzi, 1992; Williams-Brinkley, 1999). These commonly-shared attributes were tested in this study.

Operational definitions for the seven vision attributes used in this study are: (a) brevity is the degree to which a vision statement contains 11-22 words; (b) clarity is the degree to which a vision statement directly points at a prime goal it wants to achieve within a clearly-indicated timeframe; (c) abstractness is the degree to which a vision statement is not a one-time goal that can be met, resulting in the vision then being discarded; (d) challenge is the degree to which a vision statement motivates members to try their best to achieve a desirable outcome; (e) future orientation is the degree to which a vision statement indicates the long-term perspective of the organization and the environment in which it functions; (f) stability is the degree to which a vision statement is unlikely to be changed by any market or technology change; and (g) desirability or ability to inspire is the degree to which a vision statement specifies a goal and how the goal directly benefits staff.

\section{Vision Content}

A successful strategic vision appears to take into account industry, customers, and an organization's specific competitive environment in identifying an innovative competitive position in the industry (Pearson, 1989). Ideally this should differentiate the content of visions across organizations (Collins \& Porras, 1994). For example, Williams-Brinkley (1999) argued that the focus of a healthcare vision should always be on customers, their families, and staff. Customer and staff satisfaction imageries were adopted as relevant vision content in this study, because it 
was expected that the more store managers envisioned satisfying customers and staff, the higher the organizational performance.

Operational definitions for vision content used in this study are: (a) customer satisfaction imagery is the degree to which a vision statement refers to increasing customer satisfaction and a specific level to which it should be increased; (b) staff satisfaction imagery is the degree to which a vision statement contains reference to increasing staff satisfaction and a specific level to which staff satisfaction should be increased.

\section{INTERVENING VARIABLES}

The literature suggests three sets of intervening factors in the visionary process are necessary for realizing a vision: Store Manager, Staff, and Organizational Factors. Operational definitions for each set of factors are presented below.

\section{Store Manager Factor}

The Store Manager Factor includes the variables of vision communication (e.g. Bass, 1985; Bennis \& Nanus, 1985; Conger \& Kanungo, 1987, 1988), passion for vision (e.g. Kotter, 1996; Nanus, 1992), behavioral consistency (e.g. Bennis, 1984; Conger \& Kanungo, 1988; Lipton, 1996), organizational alignment (e.g. Conger \& Kanungo, 1988; Kotter, 1990; Kouzes \& Posner, 1987), ability to exercise authority to implement vision plans (e.g. Bass, 1985; Bennis \& Nanus, 1985), empowerment (e.g. Conger \& Kanungo, 1987; Cowley \& Domb, 1997), and motivation (e.g. Awamleh \& Gardner, 1999; Bass, 1985).

Operational definitions for the Store Manager Factor variables are: (a) vision communication is the degree to which a store manager communicates his/her vision via spoken, written, and technology-mediated channels; (b) passion for the vision is defined as the degree to which a store manager is passionate about his/her vision; (c) behavioral consistency is defined as the degree to which a store manager acts consistently with his/her vision; (d) organizational alignment is the degree to which a store manager aligns people and supporting systems to suit his/her vision; (e) ability to exercise authority is the degree to which a store manager feels constrained to exercise his/her authority in implementing his/her vision; (f) empowerment is the degree to which a store manager empowers his/her staff; and (g) motivation is the degree to which a store manager energizes his/her staff.

\section{Staff Factor}

The Staff Factor includes the variables of vision guiding (e.g. Conger \& Kanungo, 1988; Lipton, 1996), shared vision (e.g. Reardon, 1991; Saskin, 1985), and emotional commitment to the vision (e.g. Collins \& Porras, 1994; Lipton, 1996). Operational definitions for the Staff Factor are: (a) vision guiding is the degree to which a staff member uses his/her store manager's vision to guide daily operations; (b) shared vision is the degree to which staff personal visions are similar to their store manager's vision; and (c) emotional commitment is the degree to which a staff member is emotionally committed to the store manager's vision.

\section{Organizational Factor}

The Organizational Factor includes the variables of financial and staff support, which managers are often said to require for realizing their visions (e.g. Cowley \& Domb, 1997; Kouzes \& Posner, 1987; Locke et al., 1991). Operational definitions for the Organizational Factor are: (a) financial support is the degree to which a store manager has received additional financial support in implementing his/her vision plan; and (b) staff support is the degree to which a store manager has received additional staff support in implementing his/her vision plan. 


\section{PERFORMANCE MEASURES}

Staff satisfaction has been cited as a performance indicator in various business organizations (e.g. Anderson, 1984; Barbin \& Boles, 1996; Tompkins, 1992; van Dyck, 1996; Yeung \& Berman, 1997), as has customer satisfaction (e.g. Bird, 1995; Gates, 2000; Sitzia \& Wood, 1997). Therefore, they were adopted as two critical performance measures in this study. Operational definitions for staff and customer satisfaction are: (a) staff satisfaction is the degree to which a staff member is satisfied with his/her job as measured by pay, fringe benefits, autonomy, task requirements, staff policies, interaction, professional status, guidance, co-workers, recognition, and career advancement (Slavitt, Stamps, Piedmont, \& Hasse, 1986); (b) customer satisfaction is the degree to which a customer is satisfied with overall store services as measured by staff availability, friendliness, decoration, presentation of goods, cleanliness, quality of goods, richness of choice, waiting time for checkout, payment methods, price labeling, special offers and sales, shopping hours, prices, and shelf/rack layout (Hackl, Scharitzer, \& Zuba, 2000).

\section{MEASUREMENT MODEL}

Since relationships among the various characteristics of a vision and organizational performance are not yet well understood, Figure 1 depicts a model proposing a link between vision and retail performance derived from the vision, business strategy, leadership, and performance literature. Two domains of variables, vision attributes and content, shown in Figure 1, are represented in a vision main effects path model that has retail performance as measured by customer and staff satisfaction as the outcome variable. The vision attributes domain includes individual variables of brevity, clarity, abstractness, future orientation, stability, inspiring, and challenge. The vision content domain encompasses the individual variables of customer and staff satisfaction imageries. Vision attributes and content can be expected to have direct effects, as shown by the solid lines, on customer and staff satisfaction.

However, a simple main effects model would suffer the limitations that the two vision domains do not necessarily afford an exhaustive explanation of retail performance, nor are customer and staff satisfaction a complete indicator of retail performance. Instead, indirect effects are proposed to operate, represented by the dotted lines linking vision attributes and content to customer and staff satisfaction via the three domain realization factors identified in the literature: Store Manager, Staff and Organizational Factors. By including the realization factors, this model is more comprehensive than a previous model developed by Baum et al. (1998), which included only vision communication as a realization variable. The following hypotheses were developed and tested accordingly:

H1: Vision attributes of brevity, clarity, abstractness, challenge, future orientation, stability, and desirability or ability to inspire are significantly associated with customer and staff satisfaction, taking into account the intervening variables of Store Manager, Staff, and Organizational Factors.

H2: Vision content of customer and staff satisfaction imageries is significantly associated with customer and staff satisfaction, taking into account the intervening variables of Store Manager, Staff, and Organizational Factors. 
Figure 1: Vision - Retail Performance Measurement Model

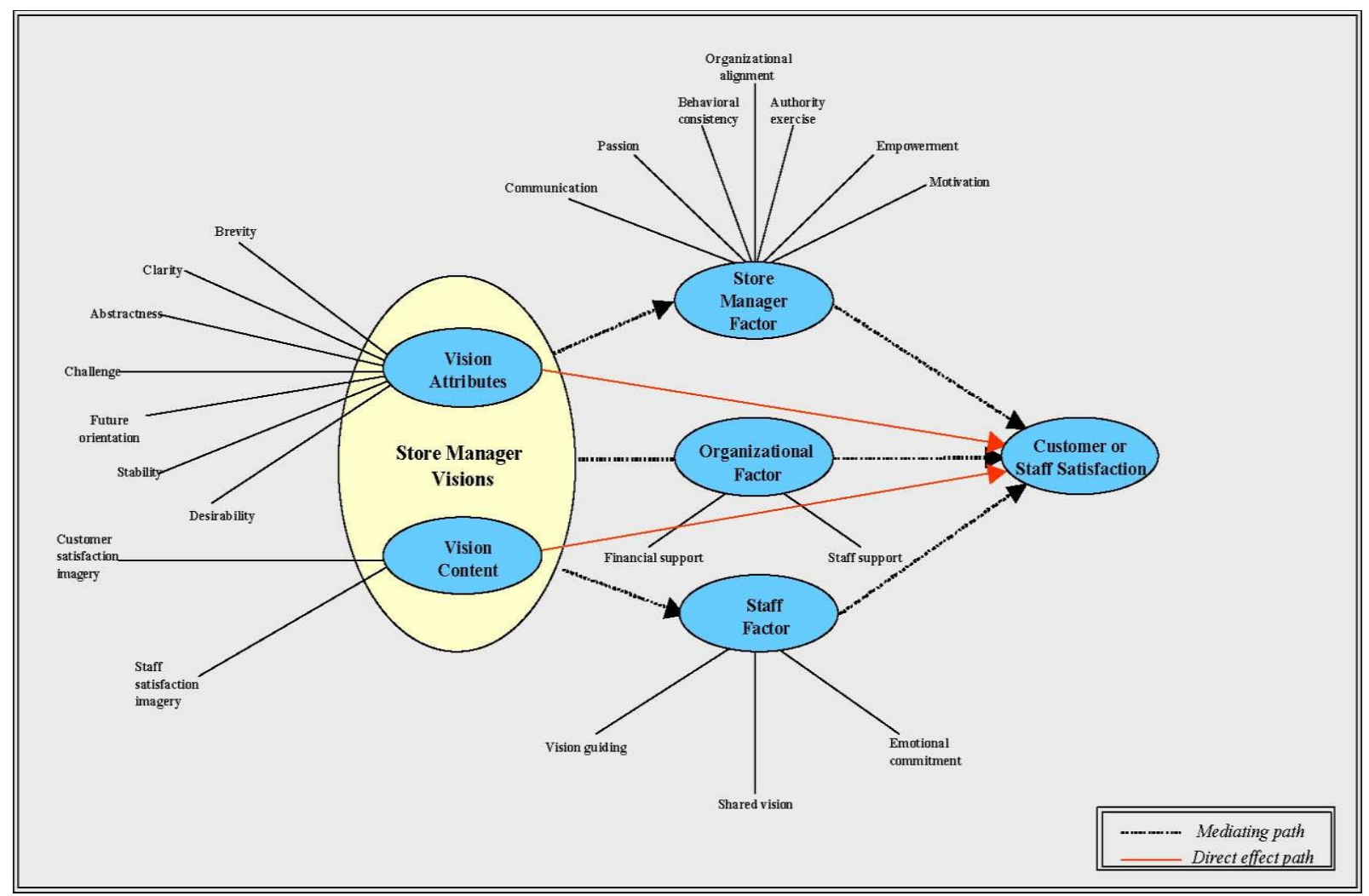

\section{METHODOLOGY}

\section{Population \& Sample}

The population was apparel stores in Sydney, Australia, referring to stores that sell brand-new, finished clothing products for individual use, excluding shoes and accessories. A store could be either a branch of a parent company or an independent business located in a shopping center or mall. All stores had their own identity, being in a clearly-defined area confined by walls. Franchised outlets were excluded. All stores within 19 shopping centers were approached and 111 stores (70\%) agreed to participate, with 48 stores (30\%) declining. From the participating stores, store managers, and staff and customers present at the time of the researcher's visit were interviewed. Store Managers refer to full-time store leaders who manage their own stores and are stationed at their stores daily. This was important because the study was interested in the effects of one manager's vision. Staff refer to fulltime, parttime and casual employees working under the store managers, and customers are individuals who were observed buying a product or service during the researcher's visit. Store managers had been with the stores for 3 years on average. Stores averaged 6 staff members in total, including 2 full-time, 2 part-time, and 4 causal staff members. Staff members consisted of full-time (30\% of respondents), part-time (23\%), and casual (47\%) respectively, and had worked in their stores for an average of 2.6 years. Among the 111 stores, 81 store managers reported having a vision.

\section{Data Collection \& Analysis}

Separate questionnaires were used for store managers, staff and customers. A 9-point, ratio scale was used for all questionnaire items measuring the six domains in the Vision - Retail Performance Measurement Model. The focus of the store manager questionnaire was to collect data on the vision and related intervening variables. The first 
group of questions in this questionnaire collected demographic information. The second set of questions concerned whether store managers had a vision for their store, what the vision was, where it came from, and to what extent they had communicated their vision to their staff. Questions measuring empowerment, motivation, passion for the vision, behavioral consistency, ability to exercise authority, and organizational alignment were also included in this questionnaire.

The focus of the staff questionnaire was on staff satisfaction and measures of vision guiding, shared vision, and emotional commitment to the vision. The first set of questions concerned staff assignment: full-time, part-time, or casual. The next set of questions related to the store manager's vision and measured vision guiding and emotional commitment to the vision. Staff were also asked to write down any personal vision they might have. The third group of questions related to the six components of job satisfaction: pay, autonomy, task requirements, organizational policies, interaction, and professional status.

The customer questionnaire collected data on overall satisfaction with services at the store and on customer satisfaction measures of staff availability, staff friendliness, decoration, presentation of goods, cleanliness, quality of goods, richness of choice, waiting time for checkout, payment methods, price labeling, special offers and sales, shopping hours, prices, and shelf/rack layout.

Three independent raters rated the collected vision statements along a 5-point scale, where 1 indicated absence of each vision attribute/content and 5 indicated strong presence of each vision attribute/content. The interrater reliability value of 0.98 exceeded 0.8 , the guideline for acceptable reliability (Fornell \& Larker, 1981). Store managers reporting no vision were included in the analysis by assigning zero to each of the vision attributes and to the content. Since vision is considered important to organizational performance, one would expect that stores with no vision would perform significantly worse than those with a vision. Finally, the shared vision value for each store was determined by correlating rated vision attribute and content scores from a store manager, and average rated personal vision attribute and content scores from staff members at each store.

All scales associated with vision attributes, customer and staff satisfaction, and Store Manager, Staff, and Organizational Factors were unidimensional (their respective measured items indicated coefficient values of more than 0.3, see Taris \& Bok, 1998). Only two scales of customer and staff satisfaction imageries did not indicate sufficient unidimensionality, but despite this, they were included in the analysis because they were significantly correlated with customer satisfaction $(\mathrm{p}<0.05)$. All scales indicated reliability values exceeding, or very close to, 0.8 , the guideline for acceptable reliability (Fornell \& Larcker, 1981). Convergent and discriminant validity were also sufficiently represented ( $<0.05$ ), although some variables expected to measure one construct were correlated with other variables intended to measure other constructs (Stangor, 1998).

Regression was used to test the five independent variables of vision attributes and content, Store Manager, Staff, and Organizational Factors against the two dependent variables of customer and staff satisfaction, one at a time. Although structural equation modeling was also considered, we chose the more traditional statistical method (e.g. Rigdon, 1997).

\section{RESULTS AND DISCUSSION}

The following sections discuss the findings on vision, the Store Manager, Staff and Organizational Factors, using $\mathrm{p}<0.05$. The averaged total vision attributes score is $12.9( \pm 9.23)$, while the averaged vision content score is $1.4( \pm 2.08)$. The averaged customer and staff satisfaction scores are $95( \pm 15.35)$ and $75.7( \pm 15.03)$ respectively. The averaged Store Manager Factor, Staff Factor, and Organizational scores are $108.8( \pm 15.85), 23.2( \pm 4.16)$, and 4.2 $( \pm 3.14)$ respectively.

\section{Vision}

From the significant relationships between the overall vision attributes domain, and customer and staff satisfaction, it can be deduced that stores with a vision performed significantly better in terms of customer and staff satisfaction than stores without a vision. Looking more closely at the visions, the vision attributes domain of brevity, 
clarity, abstractness, challenge, future orientation, stability, and desirability or ability to inspire was significantly related to customer satisfaction, according to the regression analysis. Only one individual variable, vision clarity, was significantly associated with customer satisfaction. Further, it was found that visions characterized by the seven attributes were significantly related to staff satisfaction. However, unlike customer satisfaction, no individual vision attribute was significantly associated with staff satisfaction. These empirical findings support claims about the importance of espousing a vision in theoretical publications (e.g. Isenberg, 1987; Maccoby, 1981; Mendall \& Gerguoy, 1984; Peters, 1987; Slater, 1993) and in research (e.g. Baum et al., 1998; Filion, 1991; Kotter, 1990; Larwood, Falbe, Kriger, \& Miesling, 1995; Westley \& Mintzberg, 1989).

The regression findings are consistent with the significant relationships found between vision attributes and organizational performance in Baum et al.'s (1998) study of entrepreneurs. In particular, the direct effect from the vision attributes on organizational performance as measured by staff satisfaction endorses a similar direct effect finding on organizational performance as measured by venture growth in the previous study. The significance of vision attributes also lends support to a recent finding that vision was an identifiable and measurable construct in Australian small firms (French, Kelly, \& Harrison, 2001).

The interesting finding on the significance of vision clarity supports assertions that the degree of clarity influences how well a vision is understood and accepted (e.g. Jacobs \& Jaques, 1990; Locke et al., 1991), and shows how to get the right thing done in an organization (e.g. Conrad, 1990; Pace \& Faules, 1989). Consistent with the vision clarity finding are claims that a lack of clear vision was a major reason for declining effectiveness in many organizations in the 1970s and 1980s (Bennis \& Nanus, 1985). One explanation for this is that a clear vision of what an organization could accomplish or become helps employees understand the purpose, objectives, and priorities in the organization (Yukl, 1998).

The regression analysis does not support the expectations about vision content referred to above. Customer and staff satisfaction imageries were not found to be significantly associated with customer and staff satisfaction. This non-significant relationship might have been induced by the fact that most reported vision statements (64\%) did not contain reference to either customer or staff satisfaction imageries, generating only a small sample of visions with such imageries. However, after analyzing only those stores with customer and staff satisfaction imageries, the non-significant relationship persisted. Caution is recommended in concluding from this finding that there is no relationship between customer and staff satisfaction imageries, and customer and staff satisfaction for two reasons. First, there was only a small sample containing these two imagery items, and second, a significant correlation was found between the two vision imageries and customer satisfaction $(\mathrm{p}<0.05)$. This correlation suggests that vision content might have an effect on customer satisfaction, but the effect might have been masked in the regression analysis by the effect of vision attributes.

\section{Store Manager Factor}

The Store Manager Factor includes empowerment, motivation, passion for vision, vision communication, behavioral consistency, ability to exercise authority, and organizational alignment. Overall, the regression findings indicated that the Store Manager Factor and vision attributes domain had significant, direct associations with staff satisfaction. However, the Store Manager Factor was not found to have any significant association with customer satisfaction in the regression analysis. This may have been because store managers are less likely to have direct contact with customers, and so, the impact of a store manager on customer satisfaction may be indirect. It may be created through staff members who use the store manager's vision to guide their daily operations, share the store manager's vision, and are emotionally committed to the vision. This indirect impact on customer satisfaction is discussed in the next section.

The charismatic and transformational leadership theories by Bass (1985), Bennis \& Nanus (1985), Conger \& Kanungo (1987), House (1977), Kouzes \& Posner (1987), Locke et al. (1991), Tichy \& Devanna (1986), Kirkpatrick \& Locke (1996) have overall gained support from the Store Manager Factor findings because these theories emphasize the positive impact of vision-based leaders on their followers, the view which is largely reflected in the Store Manager Factor findings. That vision is a fundamental attribute of effective leadership and the basis of one's power to lead (Kouzes \& Posner, 1987; Quigley, 1993) is also endorsed by the present findings. 


\section{Staff Factor}

The Staff Factor includes vision guiding, shared vision, and emotional commitment to vision. Overall, the regression findings indicated that although the Staff Factor was significantly related to both customer and staff satisfaction, the Store Manager Factor was more important to staff satisfaction than the Staff Factor. While the Staff Factor was significantly associated with staff satisfaction, the effect of the Staff Factor was probably masked by the effects of the vision attributes domain and the Store Manager Factor. The significant effect of the Staff Factor on customer satisfaction was also masked fully when Store Manager, Organizational, and Staff Factors were taken into account, although none of these variables was found significant.

\section{Organizational Factor}

The Organizational Factor was not significantly associated with customer and staff satisfaction in the regression analysis, contradicting the view in the literature that visionary leaders need to acquire support for their vision from relevant stakeholders (e.g. Cowley \& Domb, 1997; Kouzes \& Posner, 1987; Locke et al., 1991; Nanus, 1992). However, this non-significant effect might be due to the fact that only 56 stores reported having a vision implementation plan, and of these only 14 and 15 reported needing additional financial and staff support for their vision implementation plan respectively. Another possible reason for the non-significant finding is that the sample in this study comprised simple, small organizations, in which additional finance and staff support may not always be needed for implementing a vision, unlike in large, complex organizations. Therefore, the reliability and validity of the Organizational Factor may have been limited by the reported data.

\section{RESEARCH IMPLICATIONS}

This study has highlighted many areas in which further research is needed into the components of vision and their relationship to organizational performance. First, additional attributes could be studied. We looked at seven widely-agreed-upon vision attributes, but other attributes may also be worthy of further investigation, including "understood" and "direct effort" (Nanus 1992), "truly radical" (Trice \& Beyer, 1986), "focus" (Jacobs \& Jaques, 1990), and "risk propensity" (Forward, Beach, Gray, \& Quick, 1991; Hitt \& Taylor, 1991). Vision has been found to be important in both small, simple organizations (Baum et al., 1998; Filion, 1991), and in large, complex organizations (e.g. Kotter, 1990; Westley \& Mintzberg, 1989), and future studies might want to investigate the effects of specific vision attributes on business performance in large, complex organizations. Further research should investigate the effects of customer and employee satisfaction imageries, and other vision content components suggested in the literature, on organizational performance, in both simple and more complex organizational settings. Since the content of a vision may focus on products, services, markets, organizations, or even ideas (Westley \& Mintzberg, 1989), there is plenty of scope for research here.

Although this study pinpoints the importance of the Store Manager Factor, more needs to be known about these realization factors. For example, little is understood about how store managers communicate their vision, become passionate about their vision, behave consistently with their vision, exercise authority to turn their vision into reality, align organizational systems to suit their vision, and empower and motivate staff. Future research may want to explore this process-related aspect of vision-based leadership further.

Future research could examine the role of a shared vision in the process of developing and/or sustaining a culture in which vision and values permeate, possibly replacing a single guiding vision. These findings could have wide managerial implications in developing organizations in increasingly heterogeneous and dynamic environments. This is because the literature on vision-based leadership primarily emphasizes the role of a leader in making organizations successful, and the role of followers has not been emphasized. This traditional concept is challenged by the significant staff-related findings in this study, and the emerging view that effective leadership requires an alignment between leader and followers (Drath, 2001). Supporting the critical role of self-managing followers in sharing a vision, and challenging the traditional single leader concept, is the new emerging form of network or organic organizations in which many organizational activities bypass the central leader, making the concept of the single central leader largely irrelevant (Avery, 2004). Tomorrow's organizations are likely to have many leaders, 
where multiple leaders sharing the same vision will be valuable as people cope with heterogeneous and dynamic environments, and issues and the knowledge required become too complicated for one leader (Avery, 2004). In this context, leadership will need to operate more through vision and values permeating the culture (Avery, 2004), which will become, or replace, the guiding vision (Drath, 1998). Further, although the significant role of staff in enhancing organizational performance has been pointed out, how staff members use vision to guide their operations, become emotionally committed, and share their store manager's vision still needs further investigation.

Claimed relationships between management support, and customer and staff satisfaction still need further research. Assertions have been made that visionary leaders acquire support for their vision and authority for changes regarding necessary organizational alignment from both internal and external stakeholders (e.g. Cowley \& Domb, 1997; Kouzes \& Posner, 1987; Locke et al., 1991; Nanus, 1992), and financial as well as human resources must also be committed to the visionary process (Sashkin, 1985), contrary to the present results. However, this study has sampling limitations in this area, and further research is needed into the elements of the Organizational Factor.

Finally, in an increasingly global world, it is important to learn whether visions are effective across different cultures. Some research suggests that visionary leadership may be universally recognized (Den Hartog, House, Hanges, \& Ruiz-Quintanilla, 1999), and certainly, vision content needs to accommodate cultural diversity (Drath, 2001). Further research could focus on the seven attributes and various culture-specific content.

\section{CONCLUSIONS AND MANAGERIAL IMPLICATIONS}

In conclusion, the findings on vision attributes suggest that having a vision is positively related to organizational performance as measured by staff and customer satisfaction, and stores without a vision performed significantly worse in terms of customer and staff satisfaction than those with a vision. Visions characterized by the seven attributes are associated with better performance than other visions. Our findings imply that a clear vision has a positive relationship with customer satisfaction, making it the most important individual vision attribute, while neither clarity nor any other individual vision attribute had a significant association with staff satisfaction. In addition, the findings suggest that the vision attributes domain was more significant than the vision content domain in terms of customer and staff satisfaction, although this may have been an artifact of the methodology. Somewhat surprisingly, vision content does not appear to be significant. This study has generated considerable further research opportunities.

The results also have practical implications for managers. Since the role of vision attributes in enhancing store performance as measured by both customer and staff satisfaction has been supported, store managers are advised to develop a vision characterized by the seven attributes to enhance customer and staff satisfaction. Store managers should pay special attention to the vision's clarity, since this appears to have a significant relationship with customer satisfaction. Achieving vision clarity means adopting a vision that points directly at a prime goal and a clearly-indicated timeframe to achieve the goal. The present findings suggest that store managers should be passionate about their vision, communicate their vision to promote change, behave consistently with their vision, exercise their authority to turn their vision into reality, align organizational systems to suit their vision, and motivate and empower their staff to enhance organizational performance. To enhance organizational performance via customer and staff satisfaction, staff members should use their store manager's vision to guide their daily operations, be emotionally committed to their store manager's vision, and share their store manager's vision. Staff emotional commitment and shared vision, in particular, are most critical to organizational performance because they were significantly correlated with both customer and staff satisfaction.

\section{REFERENCES}

1. Anderson, C. H. 1984. Job design: employee satisfaction and performance in retail stores. Journal of Small Business Management, 22(4): 9-16.

2. $\quad$ Avery, G. C. 2004. Understanding Leadership. London: Sage.

3. Awamleh, R., \& Gardner, W. 1999. Perceptions of leader charisma and effectiveness: The effects of vision content, delivery, and organizational performance. Leadership Quarterly, 10(3): 345-373. 
4. Barbin, B. J., \& Boles, J. S. 1996. The effects of perceived co-worker involvement and supervisor support on service provider role stress, performance and job satisfaction. Journal of Retailing, 72(1): 57-75.

5. Barling, J., Weber, T., \& Kelloway, E. K. 1996. Effects of transformational leadership training on attitudinal and financial outcomes: A field experiment. Journal of Applied Psychology, 81: 827-832.

6. Bass, B. M. 1985. Leadership and Performance Beyond Expectations. New York: Free Press.

7. Bass, B. M. 1990. Bass \& Stogdill's Handbook of Leadership: Theory, Research, \& Managerial Applications(3rd ed..). New York: Free Press.

8. Baum, I. R., Locke, E. A., \& Kirkpatrick, S. A. 1998. A longitudinal study of the relation of vision and vision communication to venture growth in entrepreneurial firms. Journal of Applied Psychology, 83: 4354.

9. Bennis, W. G. 1984. The four competencies of leadership. Training \& Development Journal, 28(8): 14-19.

10. Bennis, W. G., \& Nanus, B. 1985. Leaders: The Strategies for Taking Charge. New York: Harper \& Row.

11. Bird, A. 1995. Performance measurement for the financial services industry. Community Banker, 1(5): 710 .

12. Collins, J. C., \& Porras, J. I. 1994. Built to Last: Successful Habits of Visionary Companies. Century: London.

13. Conger, J. A. 1991. Inspiring others: the language of leadership. Academy of Management Executive, 5(1): $31-45$

14. Conger, J. A., \& Kanungo, R. N. 1987. Toward a behavioral theory of charismatic leadership in organizational settings. Academy of Management Review, 12: 637-647.

15. Conger, J. A., \& Kanungo, R. N. 1988. Charismatic Leadership: The Elusive Factor in Organizational Effectiveness. San Francisco, CA: Jossey-Bass.

16. Conrad, C. (1990). Strategic Organizational Communication: An Integrated Perspective. Orlando, FL: Harcourt Brace Jovanovich College Publishers.

17. Cowley, M., \& Domb, E. 1997. Beyond Strategic Vision. Boston: Butterworth-Heinemann.

18. Den Hartog, D. N. \& Verburg, R. M. 1997. Charisma and rhetoric: Communicative techniques of international business leaders. Leadership Quarterly, 8: 355-391.

19. Drath, W. H. 1998. Approaching the Future of Leadership Development. Greensboro, NC: Center for Creative Leadership.

20. Drath, W. H. 2001. The Deep Blue Sea: Rethinking the Source of Leadership. San Francisco, CA: JosseyBass.

21. Filion, L. J. 1991. Vision and relations: Elements for an entrepreneurial metamodel. International Small Business Journal, 9: 112-131.

22. Fornell, C. \& Larcker, D. 1981. Evaluating structural equation models with unobservable variables and measurement error Journal of Marketing Research, 18(February): 39-50.

23. Forward, G. E., Beach, D. E., Gray, D. A., \& Quick, J. C. 1991. Mentofacturing: A vision for American industrial excellence. Academy of Management Executive, 5(3): 32-44.

24. French, S. N., Kelly, S. J., \& Harrison, J. L. 2001. Operationalising Vision and Mission. Journal of the Australian and New Zealand Academy of Management, 7(2): 30-40.

25. Hackl, P., Scharitzer, D., \& Zuba, R. 2000. Customer satisfaction in the Austrian food retail market. Total Quality Management, 11(7): S999-S1006.

26. Hitt, M. A. \& Tyler, B. B. 1991. Strategic decision models: Integrating different perspectives. Strategic Management Journal, 12(5): 327-351.

27. House, R. J. 1977. A 1976 theory of charismatic leadership. In J. G. Hunt, \& L. L. Larson (Eds.), Leadership: The Cutting Edge (pp. 189-207). Carbondale: Southern Illinois University Press.

28. Howell, J. M., \& Avolio, B. J. 1993. Transformational leadership, transactional leadership, locus of control, and support for innovation: Key predictors of consolidated-business-unit performance. Journal of Applied Psychology, 78: 891-902.

29. Isenberg, D. J. 1987. The tactics of strategic opportunism. Harvard Business Review, March-April: $92-97$.

30. Jacobs, T. O., \& Jaques, E. 1990. Military executive leadership. In K. E. Clark, \& M. B. Clark (Eds.), Measures of Leadership (pp. 281-295). West Orange, NJ: Leadership Library of America.

31. Kirkpatrick, S. \& Locke, E. 1996. Direct and indirect effects of three core charismatic leadership 
components on performance and attitudes. Journal of Applied Psychology, 84(1): 36-51.

32. Kotter, J. P. 1990. A Force for Change: How Leadership Differs from Management. New York: Free Press.

33. Kotter, J. P. 1996. Leading Change. Boston, MA: Harvard Business School Press.

34. Kouzes, J. M., \& Posner, B. Z. 1987. The Leadership Challenge: How to get Extraordinary Things Done in Organizations. San Francisco: Jossey-Bass.

35. Larwood, L., Falbe, C. M., Kriger, M, R, \& Miesling, P. 1995. Structure and meaning of organization vision. Academy of Management Journal, 85: 740-769.

36. Lipton, M. 1996. Demystifying the development of an organizational vision. Sloan Management Review, 37(4): 83-91.

37. Locke, E. A., Kirkpatrick, S., Wheeler, J. K., Schneider, J., Niles, K., Goldstein, H., Welsh, \& Chah, D. O. 1991. The Essence of Leadership. New York: Lexington Books.

38. Maccoby, M. 1981. The Leader. New York: Simon \& Schuster.

39. Mendall, J. S. \& Gerguoy, H. G. 1984. Anticipatory management or visionary leadership: A debate. Management Planning, 33(November-December): 28-31.

40. Nanus, B. 1992. Visionary Leadership: Creating a Compelling Sense of Direction for Your Organization. San Francisco, CA: Jossey-Bass.

41. Pace, R. W. \& Faules, D. F. 1994. Organizational Communication (3rd. Ed..). Englewood Cliffs, New Jersey: Prentice Hall.

42. Pearson, A. E. 1989. Six basics for general managers. Harvard Business Review, 67(4): 94-101.

43. Peters, T. J. 1987. Thriving on Chaos: Handbook for A Management Revolution. New York: Harper and Row.

44. Queensland Health 1998. 1998-2003 Corporate Plan.

45. Quigley, J. V. 1993. Vision: How Leaders Develop it, Share it, and Sustain it. New York: McGraw-Hill.

46. Reardon, K. K. 1991. Persuasion in Practice. Newbury Park, California: Sage.

47. Rigdon, E. E. 1997. Lisrel: Issues, debates and strategies/Lisrel approaches to interaction effects in multiple regression. Journal of Marketing Research, 34(4): 537-540.

48. Robbins, S. R., \& Duncan, R. B. 1988. The role of the CEO and top management in the creation and implementation of strategic vision. In D. C. Hambrick (Ed.), The Executive Effect: Concepts and Methods for Studying Top Managers (p. 137-162). Greenwich, CT: JAI Press.

49. Sashkin, M. 1988. The visionary leader. In J. A. Conger, \& R. N. Kanungo (Eds.), Charismatic Leadership: The Elusive Factor in Organizational Effectiveness (p. 122-160). San Francisco: Jossey-Bass.

50. Sashkin, M. 1992. Strategic leadership competencies: An introduction. In R. L. Phillips, \& G. Hunt (Eds.), Strategic Leadership: A Multiorganization-level Perspective, (p. 139-160), Westport, CT: Quorum.

51. Seeley, D. S. 1992. Visionary leaders for reforming public schools. Paper presented at the Annual Meeting of the American Educational Research Association. San Francisco, CA.

52. Senge, P. M. 1990. The Fifth Discipline: The Art \& Practice of the Learning Organization. New York: Currency Doubleday.

53. Sims, H. P., Jr., \& Lorenzi, P. 1992. The New Leadership Paradigm: Social Learning and Cognition in Organizations. Newbury Park, CA: Sage.

54. Sitzia, J., \& Wood, N. 1997. Customer satisfaction: A review of issues and concepts. Social Science Medical, 45(12): 1829-43.

55. Slater, R. 1993. The New GE: How Jack Welch Revived an American Institution. Homewood, IL: Business One Irwin.

56. Slavitt, D., Stamps, P., Piedmont, E., \& Hasse, A. 1986. Index of work satisfaction. MI: University of Michigan Press.

57. Stangor, C. 1998. Research Methods for the Behavioral Sciences. New York: Houghton Mifflin.

58. Taris, W. T. \& Bok, I. A. 1998. On gender specificity of person characteristics in personnel advertisements: A study among future applicants. Journal of Psychology, 132(6): 593-610.

59. Tichy, N. M., \& Devanna, M. A. 1986. The Transformational Leader. New York: Wiley.

60. Tompkins, N. C. 1992. Employee satisfaction leads to customer service. HR Magazine, 37(11): 93-97. 
61. Trice, H. M. \& Beyer, J. M. 1986. Charisma and its routinization in two social movement organization. In Staw, B. M. \& Cummings, L. L. (Eds.). Research in Organizational Behavior (113-164). Greenwich, CT: JAJ Press.

62. van Dyck, B. 1996. Employee satisfaction one factor of top performing banks. Northwestern Financial Review, 181(19): 5.

63. Wall, B., Solum, R. S., \& Sobol, M. R. 1992. The Visionary Leader. Rocklin, CA: Prima.

64. Westley, F. \& Mintzberg, H. 1989. Visionary leadership and strategic management. Strategic Management Journal, 10: 17-32.

65. Wheatley, M. J. 1999. Leadership and the New Science: Discovering Order in a Chaotic World, ( $2^{\text {nd }}$ ed). San Francisco: Berrett-Koehler.

66. Williams-Brinkley, R. 1999. Excellence in customer care demands a clear vision in action. Health Care Strategic Management, 17(1): 18-19.

67. Yeung, A., \& Berman, B. 1997. Adding value through human resources: Reorienting human resource measurement to drive business performance. Human Resource Management, 36(3): 321-335.

68. Yukl, G. A. 1998. Leadership in Organizations (4th ed.). New Jersey: Prentice Hall.

\section{NOTES}

